\author{
${ }^{1}$ Forschungsinstitut für die Biologie landwirtschaftlicher Nutztiere (FBN), Dummerstorf, Germany \\ ${ }^{2}$ Freie Universität Berlin, Berlin, Germany \\ ${ }^{3}$ Agrarwissenschaftliche Fakultät der Universität Rostock, Rostock, Germany \\ GERTRAUDE FREYER ${ }^{1}$, RUDOLPH STAUFENBIEL ${ }^{2}$, ECKHARD FISCHER ${ }^{3}$ and \\ LOTHAR PANICKE ${ }^{1}$
}

\title{
Parameters of glucose tolerance test traits in dairy cattle
}

\begin{abstract}
Numerous studies in dairy cattle focused on measuring the content of hormones, metabolites and enzyme activities in blood. Response on glucose challenge in 620 dairy bulls within a defined period of $340 \ldots 450$ days of age is targeted on within this paper. The time response course after glucose challenge was the basis for selecting corresponding response traits. Deviation from normal distribution was taken into account by means of comparing parameters of original data, after logarithmic transformation and breeding values obtained from both. The residual plots did not confirm the necessity of logarithmic transformation. After evaluating fixed effects trait-specifically, individual breeding values for glucose tolerance test traits were estimated. Heritability coefficients were promising for using these traits in cattle breeding. Trait specific heritability coefficients for G0 was 0.22 and 0.26 , for Ga 0.23 and 0.18 , for GHL 0.31 and 0.39 from logarithmic and original trait observations, respectively.
\end{abstract}

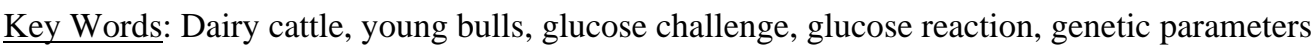

\section{Zusammenfassung \\ Titel des Beitrages: Parameter des Glukose-Toleranz-Tests (GTT) beim Milchrind}

Zahlreiche Studien beziehen sich auf die Messung der Konzentration von Hormonen und Metaboliten sowie der Enzymaktivität im Blut. Der vorliegende Beitrag untersucht die Reaktion von 620 Jungbullen, die sich in einer definierten Altersperiode von 340 bis 450 Tagen befanden, nach Glukoseinfusion. Die zeitliche Verlaufskurve nach der Glukoseinfusion war die Basis für die Auswahl entsprechender Reaktionsmerkmale des GTT. Die Originalmesswerte, logarithmisch transformierte Werte sowie Zuchtwerte aus beiden wurden zur Überprüfung der Abweichung von der Normalverteilung verglichen. Die Darstellung der Residuen bestätigte die Notwendigkeit der logarithmischen Transformation nicht. Nach der merkmalsspezifischen Berücksichtigung der fixen Effekte wurden individuelle Zuchtwerte für Merkmale des GTT geschätzt. Die Heritabilitätskoeffizienten lassen eine mögliche züchterische Nutzung dieser Merkmale in der Milchrindzüchtung erwarten. Sie betrugen für G0 0.22 und 0.26 , für Ga 0.23 und 0.18 sowie für GHL 0.31 und 0.39 , jeweils für logarithmierte bzw. absolute Beobachtungswerte.

Schlüsselwörter: Milchrind, Jungbullen, Glukosereaktion, genetische Parameter

\section{Introduction}

Suitability of quantitative-physiologic traits, e.g. of hormones, metabolites and activities of enzymes, being additional information for selection was investigated by numerous studies. The results reached so far contribute to a better understanding of physiological and biochemical relationships of genetic differences in performances. However, such results do not provide a way for developing new traits for practical selection. Just measuring of metabolites content is most likely not sufficient in this concern. Insulin has a central role within the energetic metabolism. The intravenous glucose tolerance test (GTT) yields a specific insulin response course. It enables a conclusion on the individual glucose- and insulin- reaction (STAUFENBIEL et al., 
1999). PANICKE et al. (2000) organized an experiment aimed at investigating glucose response of growing dairy bulls, following glucose challenge, based on practical conditions within two testing stations. Results of investigations in the effect of age at GTT on the relationship of GTT traits and milk production traits focus on the prepubertal age between 12 and 14 months of life. The importance of this period has been found to be significant for adapting the GTT successfully, and results on that were published recently (PANICKE et al., 2000a and 2001; STAUFENBIEL et al., 1999). The time period between 12 and 14 months of age could be of importance for dairy cattle breeding purposes, whereas other studies based on testing dairy cattle at younger ages did not lead to any conclusion in favour of a genetic relationship between milk traits and response on glucose challenge (e.g. REINICKE, 1993; ROBINSON et al., 1994; LØVENDAHL, 1997; SØRENSEN et al., 2000). Further, the reports by PANICKE et al. also include a stepwise estimation of genetic parameters. The authors also suggested a way for using the individual information on glucose tolerance test in calculating breeding values in milk production (PANICKE et al., 2001). First results seemed to be quite promising in order to use them for breeding purposes, but it is necessary to reproduce them on the basis of an extensive dataset and probably under different management conditions.

The aim of this report is to present parameter estimates of GTT- traits based on the total number of 620 animals, testing age about $12 \ldots 14$ months, within the experiment mentioned above and discussing them with respect to some aspects affecting their usefulness for breeding purposes. The genetic aspect is on focus, by means of the individual ability to react on glucose challenge.

\section{Material and Methods}

Animals and brief description on GTT: The glucose tolerance test in dairy cattle was described by STAUFENBIEL et al. (1999). An intravenous injection of $1 \mathrm{~g}$ glucose per $\mathrm{kg}$ metabolic body weight (bw $\mathrm{kg}^{0.75}$ ) was carried out, after exposing the animals to a specific diet for a prescribed time (BURKERT, 1998). Ten blood probes within 63 minutes were taken for describing an individual glucose reaction.

We consider five traits of GTT:

- glucose basal content in mmol/l (G0)

- glucose maximum content in mmol/l (Gmax1)

- difference of glucose basal content and glucose maximum content in mmol/l (Gmax)

- glucose area equivalent (Ga)

- glucose half life in min (GHL).

A more detailed outline has been reported by STAUFENBIEL et al. (1999) and (BURKERT, 1998). Observations (blood probes) of 620 young bulls, born in 1998 to 2003, managed in two testing stations, were available for GTT. For a description of GTT-traits and their basic statistic parameters see Figure 1 and Table 1 . Whereas the means of the trait observations did not show remarkable differences, besides of glucose area equivalent (difference between station 1 and 2 was $4.3, p<0.001$ ), the standard deviations (SD\%) did. According to an F-test the differences in phenotypic standard deviations were significant in G0, Gmax and Ga $(p<0.001)$. The trait variations were higher in station 2, apart from G0, that was higher in station 1 . The 
pedigree information with up to two generations of ancestors contained 1661 animals, out of them were 756 base parents. The total number of sires was 150 (from 75 paternal grand sires), where only 36 sires had five and more sons, out of them four sires had 20 and more sons (Figure 2). On the maternal side, 80 dams had more than one son. A genetic difference between the stations is not assumed since the most frequently used sires and 147 maternal grand sires had simultaneous offspring in both stations. Thus, the ancestral basis within both stations is similar. Besides of that, several bulls tested in one station were reared in the other. Sires are distributed across both stations. The different SD was due to different management conditions but not due to genetic differences. This could be shown by the four sires with more than 20 sons. Their variability within the traits, is higher in station 1 than in station 2 (Table 9). 17 testing groups were formed, each comprising at least 20 animals in each station. The testing groups were basically comparable to quarters of a year (min. 2.5 months, max 4 months) from February 1998 to December 2004 (Figure 3). This kind of grouping was used, deviating from the usual year and season raster, in order to take effects of four different test persons during the whole experiment simultaneously into account. Each single test person was responsible for testing bulls in both stations during several subsequent test time periods. The age at testing was between 344 and 450 days (Figure 4). Some conditions being important for investigations in metabolism were different in station 1 and station 2. Bulls in station 2 were 6 days younger in average, with simultaneously $37 \mathrm{~kg}$ more body weight than animals in station 1 (Table 2). Such differences are due to different feeding and management conditions.

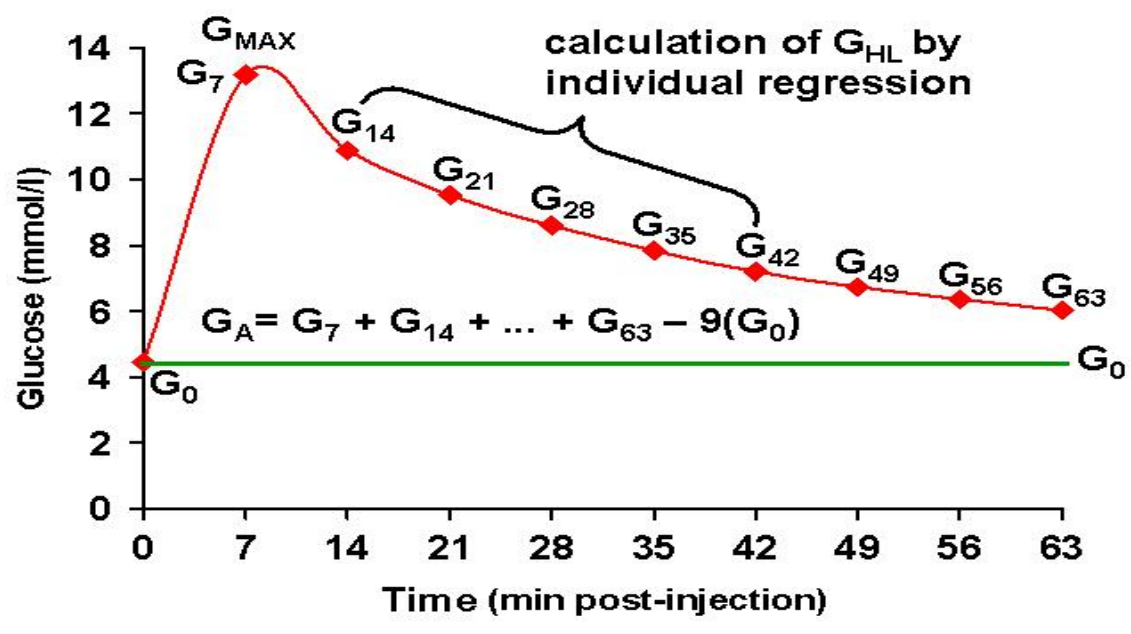

Fig. 1: Time response course within GTT with $\mathrm{G}_{0} \ldots . \mathrm{G}_{63}$ being the glucose content between injection (G0) and 63 min past injection $\left(\mathrm{G}_{63}\right)$. For more description on the traits see text above (Merkmale des Glukose-ToleranzTests (Beschreibung siehe Text) und zeitliche Verlaufskurve mit $G_{0} \ldots G_{63}$ als Glucosekonzentration zwischen Injektion und 63 min nach Injektion) 


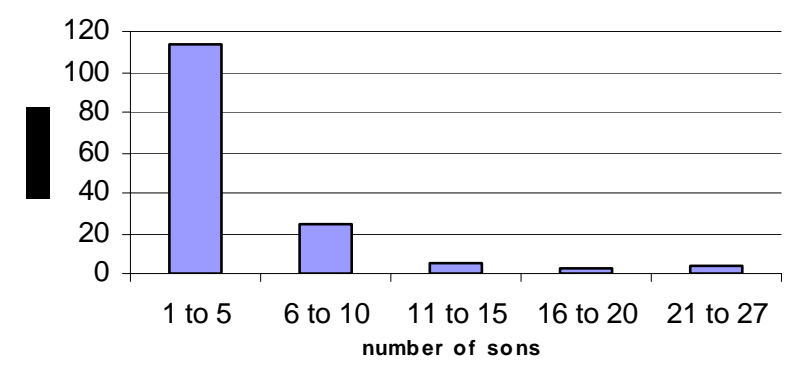

Fig. 2: Distribution of number of sons within sires (Verteilung der Väter nach der Anzahl ihrer Söhne)

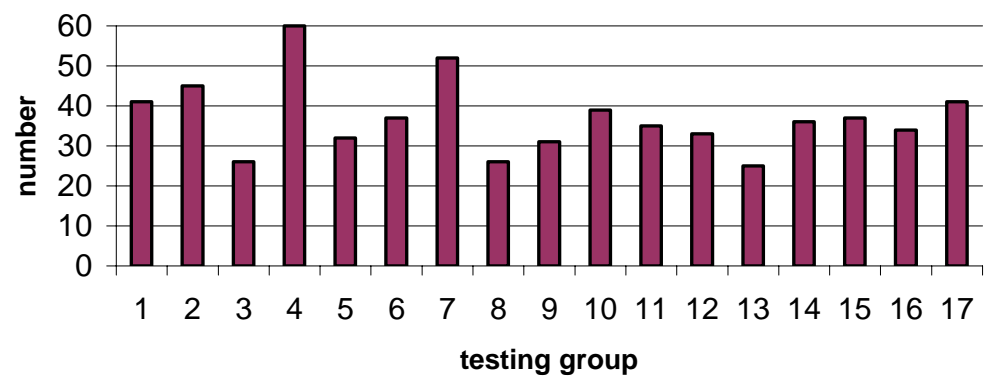

Fig. 3: Distribution of observations within test groups, comprising about quarters of a year, from April 1999 till December 2004 (Verteilung innerhalb Testzeitgruppen, die etwa ein Vierteljahr umfassen, April 1999 bis Dezember 2004)

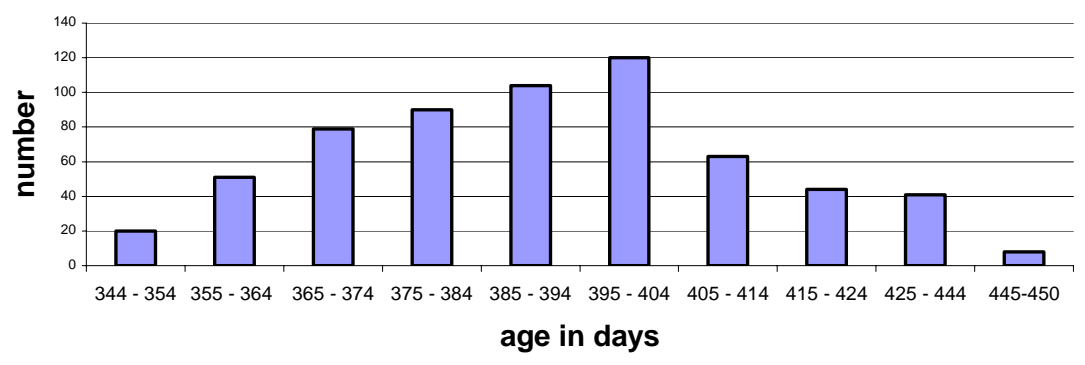

Fig. 4: Age distribution of tested bulls (Verteilung der getesteten Bullen nach dem Lebensalter)

Statistical analyses: Trait observations obtained from GTT are usually not normally distributed. As shown in Table 3, e.g. by skewness and kurtosis being in agreement with Shapiro-Wilk- and Kolmorgorov-Smirnov-Test, the only trait that was normally distributed was glucose area equivalent $(\mathrm{Ga})$. These data was transformed into a logarithmic scale. This transformation had a good effect on both glucose maximum traits (Gmax and Gmax1) and glucose half life (GHL), but the opposite effect on glucose base line (G0) and Ga was noticed. These parameters were compared for breeding values as well. Here, the estimated trait specific parameters are presented for original and logarithmic trait values in parallel.

On the basis of individual observations in GTT traits the breeding values were estimated using PEST (GROENEVELD et al., 1993). The variance components for the genetic component needed for estimating breeding values were estimated by VCE 
(GROENEVELD, 1998). The fixed effects of herd, season and age (three groups of equal size in days within the selected period of 340 to 450 days of life) were considered.

The general model for the estimation was

$\begin{array}{lll} & y_{i j k l}=m+h_{j}+c_{k}+a_{i}+e_{i j k l} \\ y_{j k l} & - & \text { observation of the } \mathrm{i}^{\text {th }} \text { animal } \\ m & - & \text { general mean } \\ h_{j} & - & \text { fixed effect of testing station and time (herd, season) } \\ c_{k} & - & \text { age-group effect within the period of } 340 \text { and } 450 \text { days } \\ a_{i} & - & \text { breeding value in GTT trait } \\ e_{i j k l} & - & \text { residual effect }\end{array}$

The SAS software (SAS Institute Inc., Cary, USA) was used for statistical material description, and further the procedure GLM for a trait-specific model comparison regarding significant fixed effects. The F-Test was used as a decision criterion. Pearson's correlation coefficient of GTT-traits was calculated via CORR procedure. For each trait, the results of seven models based on combining fixed effects (involving/dropping them, departing from the full model that includes all of them) were compared. These fixed effects were station, testing group, interaction of station * testing group, age group (or age in days as a regression coefficient) and interaction of station * age group, within the model tested for fit. Additionally, the residuals (part of individual value that was not declared by the model specified) were plotted against the predicted values from GLM procedure. The age (in days) was used as a regression variable for a better resolution of the cloud of spots in plotting the residuals, whether or not its effect on the specific trait was significant.

\section{Table 1}

Mean, standard deviation (SD) and variation coefficients (SD\%) of GTT traits in 620 growing bulls, mean age was $391 \pm 22$ days (Mittelwert, Standardabweichung und Variationskoeffizient der GTT-Merkmale von 620 Jungbullen mit einem mittlerem Alter von $391 \pm 22$ Tagen)

\begin{tabular}{|c|c|c|c|c|c|c|}
\hline $\begin{array}{l}\text { trait } \\
\text { (GTT) }\end{array}$ & $\begin{array}{l}\text { absolute } \\
\text { mean }\end{array}$ & SD & $\mathrm{SD} \%$ & $\begin{array}{l}\text { logarithmic } \\
\text { mean }\end{array}$ & SD & $\mathrm{SD} \%$ \\
\hline \multicolumn{7}{|c|}{ total, $n=620$} \\
\hline G0 & 4.488 & 0.572 & 12.74 & 1.491 & 0.146 & 9.79 \\
\hline Gmax1 & 13.359 & 1.446 & 10.82 & 2.586 & 0.103 & 3.98 \\
\hline Gmax & 8.870 & 1.424 & 16.05 & 2.171 & 0.152 & 7.00 \\
\hline $\mathrm{Ga}$ & 36.894 & 8.322 & 22.56 & 3.581 & 0.237 & 6.61 \\
\hline \multicolumn{7}{|c|}{ station $1, n=346$} \\
\hline G0 & 4.301 & 0.576 & 13.39 & 1.448 & 0.154 & 10.64 \\
\hline Gmax1 & 13.451 & 1.451 & 10.79 & 2.594 & 0.098 & 3.78 \\
\hline Gmax & 9.151 & 1.291 & 14.11 & 2.205 & 0.133 & 6.03 \\
\hline $\mathrm{Ga}$ & 38.789 & 7.650 & 19.72 & 3.638 & 0.203 & 5.58 \\
\hline \multicolumn{7}{|c|}{ station $2, n=274$} \\
\hline G0 & 4.725 & 0.470 & 9.94 & 1.547 & 0.113 & 7.30 \\
\hline Gmax1 & 13.242 & 1.521 & 11.49 & 2.577 & 0.107 & 4.15 \\
\hline Gmax & 8.516 & 1.505 & 17.67 & 2.127 & 0.162 & 7.62 \\
\hline $\mathrm{Ga}$ & 34.501 & 8.531 & 24.73 & 3.508 & 0.257 & 7.33 \\
\hline GHL & 48.933 & 14.452 & 29.53 & 3.849 & 0.293 & 7.61 \\
\hline
\end{tabular}


Table 2

Mean and standard deviation (SD) of body weight, back fat-thickness and age at testing, overall and within station 1 and 2 ( Mittelwert und Standardabweichung SD für Körpermasse, Rückenfettdicke und Testalter für gesamt sowie Station 1 und Station 2)

\begin{tabular}{lrrrrrrrrr}
\hline trait & \multicolumn{3}{c}{ total } & \multicolumn{3}{c}{ station 1 } & \multicolumn{2}{r}{ station 2 } \\
\cline { 2 - 9 } & number & mean & SD & number & mean & SD & number & mean & SD \\
\hline body weight (kg) & 577 & 436.64 & 45.93 & 328 & 420.50 & 38.45 & 249 & 457.89 & 46.40 \\
back fat-thickness & 378 & 10.80 & 2.48 & 230 & 10.31 & 2.11 & 148 & 11.56 & 2.80 \\
(mm) & & & & & & & & & \\
age (days) & 620 & 391.49 & 21.93 & 346 & 394.75 & 20.12 & 274 & 387.36 & 23.42 \\
\hline
\end{tabular}

Table 3

Additional parameters to characterize the GTT- traits with respect to their distribution before and after logarithmic transformation (Zusätzliche Parameter zur Charakterisierung der GTT- Merkmale hinsichtlich ihrer Verteilung vor und nach der Logarithmierung)

\begin{tabular}{llllll}
\hline Original data & G0 & Gmax1 & Gmax & Ga & GHL \\
\hline Skewness & -1.013 & 1.410 & 1.320 & 0.312 & 1.021 \\
Kurtosis & 3.433 & 3.803 & 3.476 & 0.811 & 2.513 \\
Shapiro- Wilk- Test & 0.952 & 0.913 & 0.923 & 0.990 & 0.954 \\
Kolmorgorov-Smirnov & 0.049 & 0.091 & 0.083 & 0.030 & 0.061 \\
\hline After logarithmic & & & & & \\
transformation & $\operatorname{lnG0}$ & $\operatorname{lnGmax} 1$ & $\operatorname{lnGmax}$ & $\operatorname{lnGa}$ & $\operatorname{lnGHL}$ \\
\hline Skewness & -2.534 & 0.880 & 0.596 & -0.707 & -0.050 \\
Kurtosis & 14.613 & 2.049 & 1.298 & 1.878 & 0.410 \\
Shapiro- Wilk- Test & 0.842 & 0.957 & 0.976 & 0.972 & 0.998 \\
Kolmorgorov-Smirnov & 0.091 & 0.067 & 0.050 & 0.049 & 0.031 \\
\hline
\end{tabular}

\section{Results and Discussion}

Pre-analyses for estimating breeding values of GTT traits: The process of estimating breeding values should be kept as simple as possible when having a practical adaptation in mind. The fixed effects are of special importance for choosing the statistical model. From a pre-analysis, by means of a simple analysis of variance (SAS, Proc. REML), significance for the only two factors station and testing group was obtained in all GTT-traits. The results of GLM-analysis were not fully consistent, such that fixed effects turned out to be of different importance for the single traits (Table 4). In principle, the main fixed effects on GTT-traits, being station and testing group, were confirmed by model comparisons, since the age effect of GTT-traits is certainly limited due to selecting those bulls tested at 344 ... 450 days of life.

From the theoretical aspect (according to significant results in Table 4), almost each single trait would need its own model to estimate breeding values. The biological background of such a finding could hardly be explained within this study. Complete trait information in GTT was necessary, while there was a lack of observations on body condition. Involving them and other related information (e.g. muscling, udder traits) could help to get a better insight into the biological mechanisms, and also into the real importance of fixed effects used in the adapted models. The effects of different models were examined further. Thereby breeding values were estimated, based on all relevant models for the GTT- traits (using PEST). The within a single trait correlation coefficients of breeding values obtained from diverse models ranged from 0.947 to 1 in Ga, and from 0.967 to 0.999 in GHL. For G0, Gmax and Gmax1, the lowest correlations of trait-specific breeding values based on different models were 0.974, 0.956 and 0.954 , respectively. Thus, the differences between breeding values estimated by different models were rather small. The only concern was including the age effect, since it was not found to be significant for most of the traits. The overall 
age effect was significant for G0 and Ga only, when including an interaction effect of age group and station (see Table 4). In more detail, the age effect was significant in $\mathrm{Ga}$ in station 1 only, (with $b=-0.051, p=0.013$ ) and in G0 (with $b=0.004$ in station 1 and $\mathrm{b}=-0.004$ in station $2, \mathrm{p}<0.01$ each). Here, $\mathrm{b}$ was the linear regression coefficient obtained by an analysis within a single station. What was the background for the opposite age effect on G0 in station 1 and 2? At this point, it can only be tried to explain these single deviations via differences in body condition, being of high importance for the individual metabolism. The averages of body condition traits (body weight and back fat-thickness) are different in both stations, but in opposite direction to the mean age (Table 2). Such trait relations being masked here might surely affect the reaction on glucose challenge and have to be investigated further in order to evaluate trait specific differences resulting from model comparisons and drawing conclusions from them in a proper way. Usually, it would be expected, that effects of differences in body condition traits on GTT-traits (based on different management conditions within the stations) will disappear by including the fixed effect station into the model. But likely some hidden interactions, e.g. of growth and fattening traits, can not be captured by this general procedure. The data was incomplete for these additional traits. Thus, for examinations on G0 and Ga the question of a separate analysis arises, since they seem to be more affected by these interactions than the other traits. Significant differences in their phenotypic standard deviations were found for station 1 and 2 in both traits (Table 2). Trait-specific differences between the stations are definitely not due to genetic differences and should be investigated further since such knowledge would be of importance for several aspects of managing and breeding cattle.

Table 4

Trait specific significant fixed effects (and p-values) obtained by the full model including fixed effects of station, testing group, interaction effect of station and testing group and age group based on GLM (in cases of p < 0.05) (Merkmalsspezifische signifikante fixe Effekte von Station, Testgruppe und Altersgruppe (und p- Werte) geschätzt mittels vollem Modell in GLM (für $\mathrm{p}<0.05)$ )

\begin{tabular}{lccccc}
\hline fixed effect & G0 & Gmax1 & Gmax & Ga & GHL \\
\hline (a) station & $0.829(.0001)$ & - & - & $-6.734(.002)$ & $7.030(.002)$ \\
(b) testing group & - & $-0.053(.0001)$ & - & - & $0.770(.028)$ \\
a*b & - & - & $-0.048(.032)$ & - & $-0.710(.002)$ \\
(c) age group & $0.326(.001)$ & - & - & $-2.755(.031)$ & - \\
a*c & $-0.217(.001)$ & - & - & $1.603(.049)$ & - \\
\hline & $\ln 0$ & $\operatorname{lnGmax} 1$ & $\operatorname{lnGmax}$ & $\operatorname{lnGa}$ & $\ln \mathrm{GHL}$ \\
\hline (a) station a & $0.208(.0001)$ & - & - & $-0.0799(.031)$ & $0.157(.0006)$ \\
(b) testing group & - & $-0.004(.0001)$ & - & $0.0122(.033)$ & $0.020(.0049)$ \\
a*b & - & - & $-0.0052(.028)$ & - & $-0.017(.0002)$ \\
(c) age group & $0.080(.0003)$ & - & - & - & - \\
a*c & $-0.053(.0001)$ & - & - & - & - \\
\hline
\end{tabular}

Results on Gmax1, Gmax, GHL, lnGmax1, lnGmax, lnGHL and lnGa written in this table were taken from the model containing fixed effects of station (a), testing group (b) and interaction $\mathrm{a}^{*} \mathrm{~b}$, since this model had a better fit for these traits than the full model including agerelated effects.

The logarithmic transformation did not yield a remarkable effect on the pattern of residual plots, neither in station 1, nor in station 2 (Figures 5 and 6). Skewness and kurtosis for breeding values were reduced by transformation (from 0.55 and 1.58 for Gmax1 to 0.43 and 1.32 for $\ln G m a x 1)$. Residual plots do not show qualitative better patterns by using logarithmic transformed values for the other traits as well (including such 'no-trend' plots, as for GHL in Figure 6). Despite a reduction of skewness and 


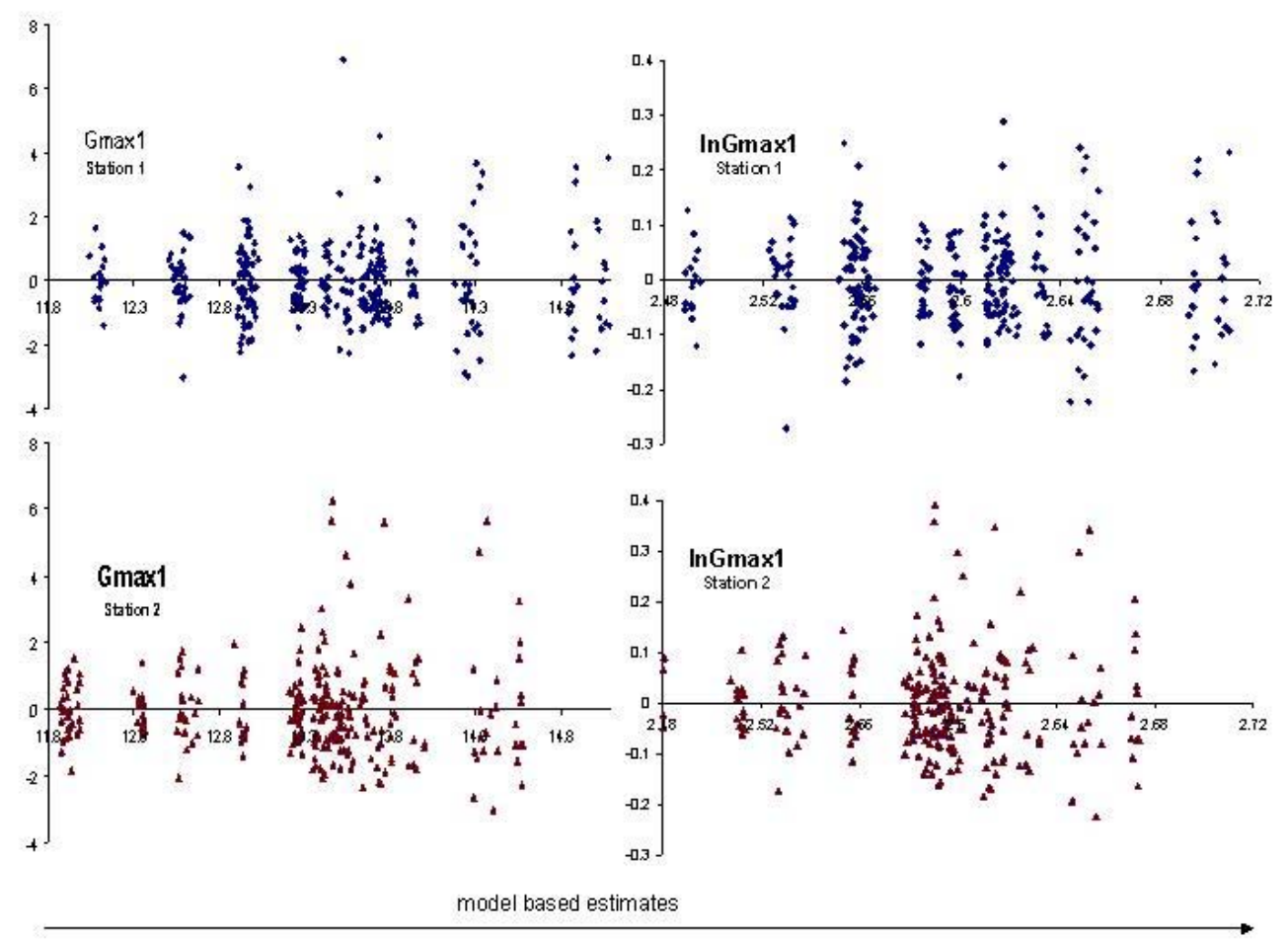

Fig. 5: Plot of residuals (on the y-axis) against estimates resulting from the whole model for Gmax1 based on original values and after logarithmic transformation separated for stations 1 and 2 (Darstellung der Residuen (yAchse) gegenüber den Schätzwerten aus dem vollen Modell für Gmax1, für Originalwerte und nach logarithmischer Transformation, getrennt nach Station 1 und 2)
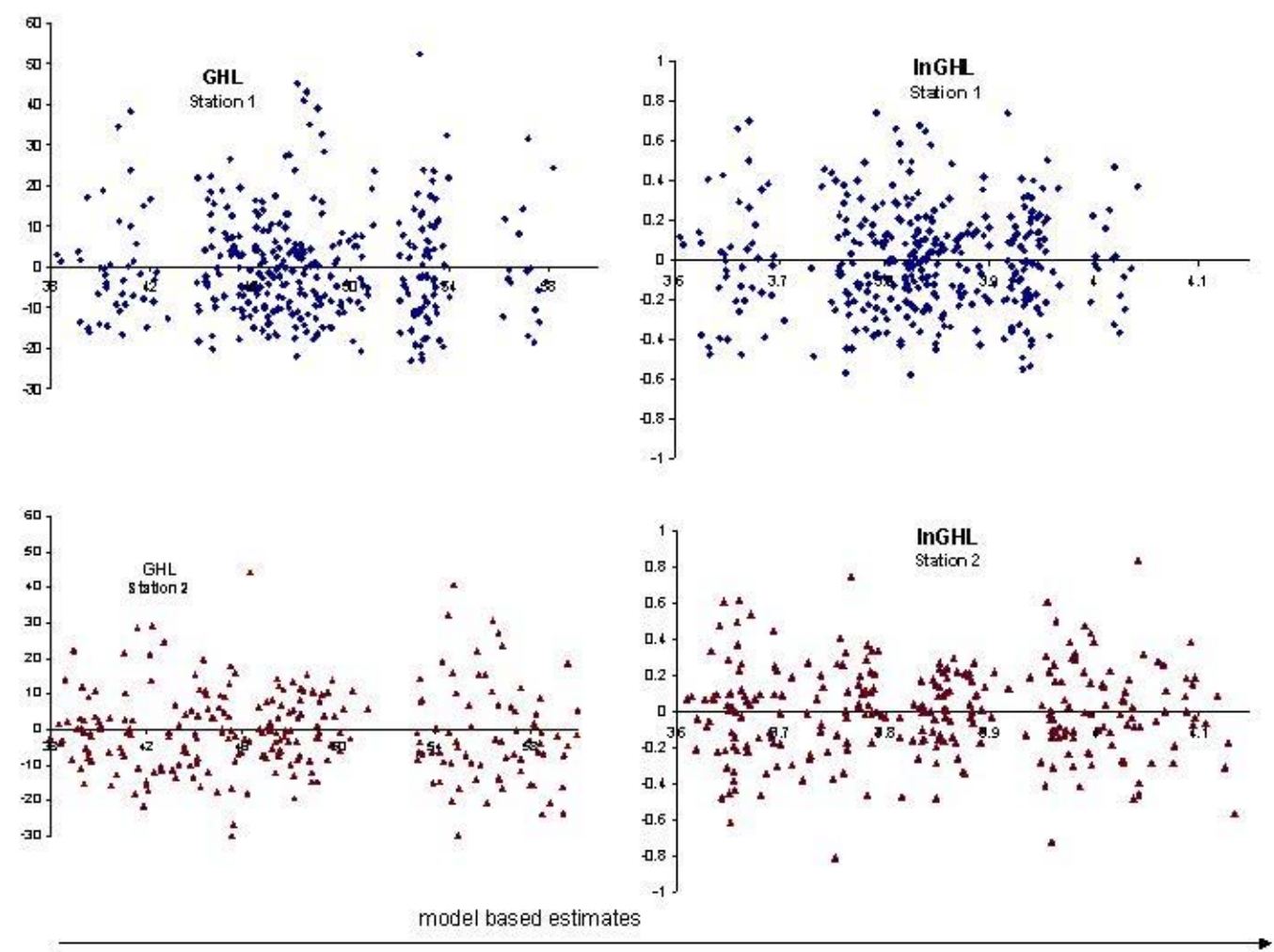

Fig. 6: Plot of residuals (on the y-axis) against estimates resulting from the whole model for glucose half life time GHL based on original values and after logarithmic transformation separated for stations 1 and 2 (Darstellung der Residuen (y- Achse) gegenüber den Schätzwerten aus dem vollen Modell für GH,L für Originalwerte und nach logarithmischer Transformation, getrennt nach Station 1 und 2) 
kurtosis for breeding values after transformation was noticed (from 0.78 and 1.82 $(\mathrm{p}<0.01)$ for GHL to $\sim 0$ and 0.033 for $\operatorname{lnGHL})$, the residual plots did not show any remarkable differences. The deviation of breeding values from normal distribution was not that high, but significant in the case of GHL. The breeding values based on logarithmic transformed data (lnGHL) were normally distributed. By means of the residual plots could not be confirmed, that the logarithmic transformation is necessary for any of the traits. Here, the results of original and transformed traits are presented in parallel in order to be comparable with the preceding reports on the experiment.

Estimates of heritability coefficients and breeding values: Heritability coefficients for glucose base line (G0) were 0.26 and 0.22 for original and logarithmic values, respectively (Table 5). Similar results with respect to this trait have been found in the literature as discussed earlier by PANICKE et al. (2001). The estimates of the heritability coefficients show considerably higher values for GTT-response traits Ga and GHL, ranging from 0.18 to 0.39 , than for Gmax and Gmax1, ranging from 0.03 to 0.08 . (Table 5). Thus, the response traits provoke expectations regarding their genetic variation that could be used for breeding purposes. Estimates of breeding values were considered for the tested animals only (Table 6).

Table 5

Heritability coefficients $\left(\mathrm{h}^{2}\right)$ and their standard errors (SE) for GTT traits (Heritabilitätskoeffizienten $\left(\mathrm{h}^{2}\right)$ und deren Standardfehler (SE) für GTT- Merkmale)

\begin{tabular}{lll}
\hline GTT trait & $\mathrm{h}^{2}$ & $\mathrm{SE}\left(\mathrm{h}^{2}\right)$ \\
\hline G0 & 0.261 & - \\
Gmax & 0.031 & - \\
Gmax1 & 0.075 & - \\
Ga & 0.226 & - \\
GHL & 0.386 & 0.117 \\
\hline $\operatorname{lnG0}$ & 0.216 & 0.079 \\
$\operatorname{lnGmax}$ & 0.031 & - \\
$\ln G \max 1$ & 0.084 & 0.059 \\
$\operatorname{lnGa}$ & 0.184 & 0.084 \\
$\operatorname{lnGHL}$ & 0.308 & 0.104 \\
\hline
\end{tabular}

(Standard errors SE $\left(\mathrm{h}^{2}\right)$ are missing in cases of unfinished optimization processes in VCE, for calculation of SE only, based on the specific model assumption)

Table 6

Mean and standard deviation (SD) of breeding values of glucose tolerance test traits within station 1 and 2 and total (Mittelwerte und Standardabweichungen der Zuchtwerte für GTT- Merkmale innerhalb Stationen und gesamt)

\begin{tabular}{|c|c|c|c|c|c|c|}
\hline \multirow[b]{2}{*}{ GTT trait } & \multicolumn{2}{|c|}{ station $1, n=346$} & \multicolumn{2}{|c|}{ station $2, n=274$} & \multicolumn{2}{|c|}{ total, $\mathrm{n}=620$} \\
\hline & mean & $\mathrm{SD}$ & mean & $\mathrm{SD}$ & mean & $\mathrm{SD}$ \\
\hline G0 & -0.009 & 0.140 & -0.011 & 0.124 & -0.010 & 0.133 \\
\hline Gmax1 & 0.008 & 0.111 & -0.018 & 0.112 & -0.004 & 0.112 \\
\hline Gmax & 0.002 & 0.043 & -0.001 & 0.044 & 0.001 & 0.043 \\
\hline $\mathrm{Ga}$ & 0.091 & 1.710 & -0.099 & 1.800 & -0.038 & 1.639 \\
\hline GHL & -0.151 & 5.202 & -0.034 & 4.895 & -0.099 & 5.065 \\
\hline $\ln G 0$ & -0.002 & 0.035 & -0.002 & 0.028 & -0.002 & 0.032 \\
\hline $\operatorname{lnGmax} 1$ & 0.002 & 0.002 & -0.004 & 0.024 & -0.001 & 0.024 \\
\hline $\operatorname{lnGmax}$ & 0.000 & 0.007 & -0.000 & 0.008 & 0.000 & 0.007 \\
\hline $\operatorname{lnGa}$ & 0.003 & 0.054 & 0.001 & 0.055 & 0.001 & 0.055 \\
\hline $\operatorname{lnGHL}$ & -0.001 & 0.084 & -0.000 & 0.080 & -0.001 & 0.082 \\
\hline
\end{tabular}

Relationship of GTT-traits: Correlation coefficients of GTT- traits obtained from original data and from breeding values are very similar in their direction (Table 7). 
Breeding values show a stronger positive correlation of $r=0.55 \ldots 0.60$, for the response traits GHL and Ga, compared to $r=0.36 \ldots 0.43$ (original data). G0 and GHL show nearly the same correlation of $r=0.24 \ldots 0.27$ for breeding values and original data. Negative correlation was obtained for Ga and G0 from original data $(r=-0.23 \ldots$ -0.21 ). A zero relationship of breeding values was obtained in both traits. The intratrait-correlations of absolute observations and breeding values (Table 7, diagonal) were much higher than expected. This correlation should be comparable to the square root of the heritability coefficient. The number of animals within only two different herds with different intrinsic conditions as for example body condition, being not completely surveyed by the fixed effects, could be a reason for such a high correlation. Body condition in terms of body weight and back fat-thickness could most likely be of importance for metabolic reactions.

Table 7

Pearson's correlation coefficients of original traits values of GTT- traits (above diagonal) and of breeding values (below diagonal) based on the whole data set (Pearsonscher Korrelationskoeffizient zwischen den GTTMerkmalen, orignale Daten oberhalb der Diagonalen, Korrelationen zwischen den Zuchtwerten unterhalb der Diagonalen)

\begin{tabular}{lcccccccccc}
\hline & \multicolumn{4}{c}{ trait values } \\
\cline { 2 - 10 } & G0 & Gmax1 & Gmax & Ga & GHL & G0 & Gmax1 & Gmax & Ga & GHL \\
\hline G0 & 0.745 & 0.237 & -0.161 & -0.229 & 0.267 & 0.742 & 0.268 & -0.167 & -0.212 & 0.255 \\
Gmax1 & 0.375 & 0.773 & 0.921 & 0.354 & -0.011 & 0.370 & 0.773 & 0.901 & 0.360 & $-0.005^{\mathrm{a}}$ \\
Gmax & $-0.032^{\mathrm{b}}$ & 0.904 & 0.751 & 0.452 & $-0.119^{\mathrm{a}}$ & $-0.036^{\mathrm{b}}$ & 0.889 & 0.782 & 0.475 & $-0.117^{\mathrm{a}}$ \\
Ga & $-0.037^{\mathrm{b}}$ & 0.374 & 0.423 & 0.722 & 0.362 & $-0.044^{\mathrm{b}}$ & 0.370 & 0.421 & 0.754 & 0.430 \\
GHL & 0.275 & $0.100^{\mathrm{a}}$ & $0.001^{\mathrm{b}}$ & 0.557 & 0.871 & 0.268 & $0.094^{\mathrm{a}}$ & $-0.009^{\mathrm{b}}$ & 0.602 & 0.897 \\
\hline
\end{tabular}

significance levels: ${ }^{\mathrm{a}} \mathrm{p}<0.05{ }^{\mathrm{b}}: \mathrm{p}>0.05 ; \mathrm{p}<0.0001$ else

Table 8

Pearson's correlation coefficients of breeding values of GTT- traits within station 1 (above diagonal) and station 2 (below diagonal) based on the whole data set (Pearsonscher Korrelationskoeffizient zwischen den GTTMerkmalen, Zuchtwerte, Station 1 oberhalb der Diagonalen, und Station 2 unterhalb der Diagonalen)

\begin{tabular}{|c|c|c|c|c|c|c|c|c|c|c|}
\hline & \multicolumn{5}{|c|}{ trait values } & \multicolumn{5}{|c|}{ logarithmic transformed } \\
\hline & G0 & Gmax1 & Gmax & $\mathrm{Ga}$ & GHL & G0 & Gmax1 & Gmax & $\mathrm{Ga}$ & GHL \\
\hline G0 & - & 0.376 & $-0.051^{b}$ & $-0.033^{b}$ & 0.306 & - & 0.374 & $-0.057^{b}$ & $-0.042^{b}$ & 0.310 \\
\hline Gmax1 & 0.381 & - & 0.900 & 0.457 & 0.176 & 0.376 & - & 0.881 & 0.465 & $0.172^{\circ}$ \\
\hline Gmax & $-0.008^{b}$ & 0.914 & - & 0.510 & $0.053^{b}$ & $-0.007^{b}$ & 0.904 & - & 0.511 & $0.037^{b}$ \\
\hline $\mathrm{Ga}$ & $-0.043^{b}$ & 0.261 & 0.305 & - & 0.642 & $-0.047^{b}$ & 0.256 & 0.313 & - & 0.670 \\
\hline GHL & 0.228 & $0.003^{b}$ & $-0.067^{b}$ & 0.436 & - & 0.199 & $-0.004^{b}$ & $-0.068^{b}$ & 0.514 & - \\
\hline
\end{tabular}

Table 9

Means, standard deviations (SD), maximum, minimum and spread of distribution (VD) of breeding values of glucose area equivalent in sires with more than 20 sons within the experiment in test stations 1 and 2 (Mittelwerte, Standardabweichung, Maximum, Minimum und Variationsbreite der Zuchtwerte für das Merkmal Glukoseflächenäquivalent nach Vätern, die mit mehr als 20 Söhnen in beiden Stationen im Experiment vertreten waren)

\begin{tabular}{cccccccc}
\hline sire ID & station & number of sons & mean & SD & min & $\max$ & VD \\
\hline 21 & 1 & 15 & 2.357 & 1.345 & -0.267 & 5.164 & 5.391 \\
& 2 & 12 & 1.190 & 1.020 & -0.456 & 2.520 & 2.975 \\
79 & 1 & 12 & -0.934 & 1.040 & -3.004 & 0.792 & 3.797 \\
& 2 & 10 & -0.212 & 1.349 & -1.820 & 1.881 & 3.701 \\
71 & 1 & 18 & 0.633 & 1.850 & -2.575 & 5.489 & 8.064 \\
& 2 & 5 & 0.413 & 1.459 & -1.586 & 2.192 & 3.878 \\
87 & 1 & 14 & -0.958 & 1.125 & -2.575 & 1.177 & 3.752 \\
& 2 & 10 & -1.508 & 0.695 & -2.618 & -0.597 & 2.021 \\
\hline
\end{tabular}


The trait correlations based on breeding values are similar within stations 1 and 2 (Table 8). The correlation coefficients between both response traits GHL and Ga are much stronger in station $1(\mathrm{r}=0.64 \ldots 0.67)$ than in station $2(\mathrm{r}=0.41 \ldots 0.51)$. Higher correlations of breeding values, found in station 1 , could be due to higher spread of distribution in sires when comparing their sons in station 1 to their sons in station 2 (as shown for Ga in Table 9). The same direction in both single stations was noticed in the case of traits G0 and GHL, with correlation coefficients $r=0.29 \ldots 0.33$ in station 1 and $r=0.20 \ldots 0.23$ in station 2, respectively. As in the full data set, both stations suggest independently that it does not seem to be a relationship between glucose base line (G0) and glucose area equivalent (Ga). Further, there is a little (partly insignificant) tendency to an opposite relationship between GHL and glucose maximum traits, tending to being stronger and positive in station $1(r=0.036 \ldots 0.185)$ than in station $2(r=-0.085 \ldots 0.010)$.

General aspects on GTT- traits: Analyses on the basis of trait observations in 620 Holstein- Friesian young bulls unravelled an amount of genetic variation that is sufficient for breeding purposes. Logarithmic transformation reduces the phenotypic standard deviation from almost $10 \ldots 30 \%$ to $4 \ldots 11 \%$ (Table 2). In any case, plotting residuals resulting from the relevant models did not reveal a better fit after logarithmic transformation, despite the deviation from normal distribution was still significant in breeding values estimated from GHL, whereas the breeding values for InGHL were normally distributed. Both original and logarithmic values were used and compared with respect to their results within the analyses, in order to estimate genetic parameters from them. Using original trait observations yielded in higher heritability coefficients with the largest difference found in GHL:

$\begin{array}{llll}\text { trait } & \text { G0 } & \text { Ga } & \text { GHL } \\ \text { original } & 0.26 & 0.23 & 0.39 \\ \text { log- transformed } & 0.22 & 0.18 & 0.31\end{array}$

A harmonized relationship of performance and health status of breeding cows and bulls should be aimed at (STAUFENBIEL et al., 2005). After analysing the whole dataset with respect to the relationship to milk performances, further prospective results of the ongoing GTT- experiment could contribute with suggestions on how to use metabolic traits in dairy cattle breeding in order to meet this aim. In concurring between several reports being different regarding conclusions from published results (e.g. ROBINSON et al., 1994; LØVENDAHL, 1997; SØRENSEN et al., 2000), and in preliminary results based on this experiment, there was a suggestion to a genetic relationship between GTT- traits and performances (e.g. PANICKE et al., 2000a). To a wide range, GTT- traits are affected by systematic environmental factors and by the metabolic status at testing time. VOIGT et al. (2005) concluded from measuring insulin within a feeding experiment that the glucose in blood can be transferred to the udder in a higher rate, whereas it is getting metabolized in fat and muscle tissue at a lower rate. Thus, muscling and udder would be important characteristics to discuss this issue. In contrary to individual insulin courses in cows during their lactation, HAMMON (2005) did not find any differences in glucose response courses following GTT under standardized experimental conditions. It still remains to be investigated on 
how specific conditions affect the variation of GTT- traits. First of all, it is to assume, that the management and feeding needs to be well defined in order to avoid covering genetic variance in GTT-traits by overweight and fattening. Further, methodical investigations are necessary and the results of breeding value estimation in performances of all 620 tested young bulls are to be waited for, in order to conduct final analyses.

\section{Acknowledgement}

Thanks to the Reviewers for helpful comments, and to Dr. Armin Tuchscherer for useful hints on handling the residual plots within SAS.

BURKERT, O.:

\section{References}

Untersuchungen zum intravenösen und modifizierten Glukosetoleranztest bei Zuchtbullen. Freie Universität Berlin, Diss. (1998)

HAMMON, H.:

GTT- results within a crossing experiment at FBN. Personal communication (2005)

LØVENDAL, P.:

Effect of selection for milk fat yield on insulin response to glucose tolerance test in prepubertal and pubertal RED dane calves. $48^{\text {th }}$ EAAP; GP 4.4, p. 41, Wien, 1997

PANICKE, L.; STAUFENBIEL, R.; BURKERT, O.; FISCHER, B.; REINHARDT, F.:

Relations between parameters of the intravenous glucose tolerance test and the breeding values of dairy bulls. Proc. 49th Annual Meeting of the EAAP, Warsawa, Poland 1998: C 5.5

PANICKE, L.; STAUFENBIEL, R.; BURKERT, O.; FISCHER, E.; REINHARDT, F.: Relations between parameters of glucose tolerance test (GTT) in young sires and their estimated breeding values of dairy bulls. J. Dairy Sci. 83, Suppl.1 (2000), 49

PANICKE, L.; STAUFENBIEL, R.; BURKERT, O.; FISCHER, E.; REINHARDT, F.:

Zusammenhang zwischen Parametern des Glukosetoleranztestes bei Jungbullen und deren Nachkommenzuchtwert. Arch. Tierz., Dummerstorf 43 (2000a) 3, 231-239

PANICKE, L.; FISCHER, E.; STAUFENBIEL, R.:

Eignung von physiologischen Merkmalen für die indirekte Eigenleistungsprüfung von Jungbullen. Arch. Tierz., Dummerstorf 44 (2001) 4, 381-394

PANICKE, L., E. FISCHER, BERND FISCHER, R. STAUFENBIEL:

Schätzung des Prüfniveaus metabolischer Merkmale beim Glukosetoleranztest (GTT) an Jungbullen. Arch. Tierz., Dummerstorf 46 (2003b) 2, 167-176

REINICKE, U.:

Der intravenöse und modifizierte Glukosetoleranztest beim Milchrind - Einflußfaktoren und Beziehungen zur Milchleistung. FU Berlin, Diss., 1993

ROBINSON, D.L.; HAMMOND, K.; MCDOWELL, G.H.:

Relationships between breeding values and physiological responses to fasting and refeeding in dairy bulls: update for young animals. J. Anim. Breed. Genet. 111 (1994), 257-264

SØRENSEN, P.; MADSEN, P.; SEJRSEN, K.; VESTERGAARD, M.; LØVENDAL, P.:

Prediction of breeding value for milk, fat and protein yield based on endocrine response profiles.. J. Dairy Sci. 83, Suppl.1 (2000), 72

STAUFENBIEL, R.; REINICKE, U.; PANICKE, L.:

Zum Glukosetoleranztest beim Rind. 1.Mitt.: Beziehungen zum Laktationsabschnitt und zur Milchleistung. Arch. Tierz., Dummerstorf 42 (1999) 1, 45-56

STAUFENBIEL, R; REINICKE, U.; BURKERT, O.; WEBER, J.; BEHN, H.; MENGEL, S.; GÖRNER, S.: Physiologische Grundlagen zur Anwendung des Glukosetoleranztests zur Beurteilung des Stoffwechselreaktionsvermögens von Rindern. Schriftenreihe Heft 15 des FBN Dummerstorf (2005), 49-64

VOIGT, J.; KANITZ, W.; SCHNEIDER, F.; BECKER, F.; SCHÖNHUSEN, U.; METGES, C. C.; HAGEMEISTER, H.; PRECHT, D.: Ernährung der Hochleistungsmilchkuh. Forschungsreport, Zeitschrift des Senates der Bundesforschungsanstalten 1 (2005), 32-35 
Received: 2005-10-28

Accepted: 2006-03-01

Author's addresses

Dr. GERTRAUDE FREYER

Forschungsinstitut für die Biologie

landwirtschaftlicher Nutztiere (FBN)

Wilhelm-Stahl-Allee 2

18196 Dummerstorf / Germany

Prof. Dr. RUDOLF STAUFENBIEL

Freie Universität Berlin

Klinik für Klauentiere

Königsweg 65

14163 Berlin / Germany

Dr. ECKHARD FISCHER

(verstorben)

Universität Rostock

Fachbereich Agrarökologie

Justus-von-Liebig-Weg

18059 Rostock / Germany

Prof. Dr. LOTHAR PANICKE*

Parkweg 16

18196 Dummerstorf / Germany

* Corresponding author 